\title{
Evaluation of Nutritional Value and Acceptability of Chicken Nuggets Produced by Chicken Wings and Dehydrated Shellfish
}

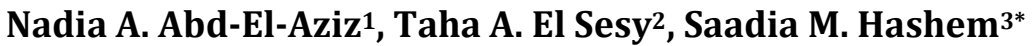 \\ ${ }^{1}$ Meat and Fish Technology Research Department, Food Technology Research Institute, Agriculture Research Center, Alexandria, Egypt \\ ${ }^{2}$ Meat and Fish Technology Research Department, Food Technology Research Institute, Agriculture Research Center, Cairo, Egypt \\ ${ }^{3}$ Food Science and Technology Department, Faculty of Agriculture, Alexandria University, Alexandria, Egypt \\ Email: *sadia.mohamed831@gmail.com
}

How to cite this paper: Abd-El-Aziz, N.A., El Sesy, T.A. and Hashem, S.M. (2021) Evaluation of Nutritional Value and Acceptability of Chicken Nuggets Produced by Chicken Wings and Dehydrated Shellfish. Food and Nutrition Sciences, 12, 805-817. https://doi.org/10.4236/fns.2021.128060

Received: July 5, 2021

Accepted: August 1, 2021

Published: August 4, 2021

Copyright ( 2021 by author(s) and Scientific Research Publishing Inc. This work is licensed under the Creative Commons Attribution International License (CC BY 4.0).

http://creativecommons.org/licenses/by/4.0/

\begin{abstract}
Our study investigated the effect of utilizing chicken wings and dehydrated shellfish to produce chicken nuggets rich in protein, minerals and vitamins. The proximate composition, nutritional value, physical and sensorial properties were evaluated. The differently prepared chicken nuggets were supplemented with dehydrated shellfish CN $0 \%, \mathrm{CN} 2 \%, \mathrm{CN} 4 \%$ and $\mathrm{CN} 6 \%$. There was a significantly reduction in moisture and an increasing in protein content $(P<0.05)$ in all Chicken Nuggets $(\mathrm{CN})$ in comparison to the control. Fat content was significantly higher in $\mathrm{CN} 0 \%$ than $\mathrm{CN} 2 \%, \mathrm{CN} 4 \%$ and $\mathrm{CN} 6 \%$. Ash content was increasing with added dehydrated shellfish, while the reduction in carbohydrates and total calories of the different chicken nuggets were noticed with the significant gradual rise in $\mathrm{pH}$ values, TBA values showed no significant difference $(P<0.05)$ between chicken nuggets. Results showed that using dehydrated shellfish in preparing chicken nuggets caused a marked rise in its content of $\mathrm{Ca}, \mathrm{Fe}, \mathrm{Na}, \mathrm{K}, \mathrm{Zn}, \mathrm{Mg}$ and $\mathrm{Mn}$ levels, $\mathrm{CN} 0 \%$ had the lowest concentration of all minerals, and had lower values of vitamins $\mathrm{A}, \mathrm{E}$ and $\mathrm{D}$ but $\mathrm{CN} 6 \%$ had higher values of vitamins $\mathrm{A}, \mathrm{E}$ and $\mathrm{D}$. Control Nuggets (CN $0 \%)$ had the lowest value of yellowness and highest value of lightness but $\mathrm{CN} 6 \%$ had the highest value of yellowness and, the lowest value of lightness. The redness had a slightly reduction. All samples showed slight changes in hardness, cohesiveness, springiness, gumminess and chewiness were noticed. An increase in WHC, pick-up, and cooking loss of chicken nuggets with dehydrated shellfish was noticed. Panelists accepted all prepared chicken nuggets and the chicken nuggets $\mathrm{CN} 4 \%$ had the highest score compared with other chicken nuggets prepared.
\end{abstract}




\section{Keywords}

Chicken Nuggets, Chicken Wings, Shellfish, Nutritional Value

\section{Introduction}

Poultry meat and chicken products have an important place in human diet, due to their positive nutritional characteristics as low lipid content, proteins of high biological value, essential amino acids and a natural source of vitamins $B_{2}, B_{3}$, and $\mathrm{B}_{6}$ and minerals such as $\mathrm{Fe}, \mathrm{P}, \mathrm{K}, \mathrm{Zn}$, and $\mathrm{Se}$ [1].

Recently, the high percentage of chicken meat and chicken products are consumed in the form of "fast food" or "ready-to-eat" products, such as chicken nuggets, due to the variety of benefits such as reduced preparation time, their low cost, and long shelf life under frozen storage.

Chicken nuggets are tasty products, favorite for children and adults, and are an important food served at almost all fast food restaurant chains increasing the demand for chicken nuggets led to the development of "value" nuggets, which replaces chicken meat with binders and extenders to decrease the cost of production [2]. Nuggets have been produced using other sources of protein, such as goat [3]. Therefore, to improve the nutritional profile of chicken products, these foods can be reformulated with health-promoting ingredients, such as fiber and vegetables, and components considered as harmful to health, like fat and additives, can be reduced or eliminated [4].

Recently, chicken wings have become a successful example of economically processed poultry products, due to their cheap price. Chicken wings contain about $7.3 \%$ fat [5]; therefore, lipid oxidation is a critical problem for marketing them. So we should remove fat before using to prepare chicken nuggets. These can be used as functional ingredients and have a great impact on the technological, nutritional, and health-promoting properties of chicken products [6].

Shellfish is a major component of seafood production. Shellfish, in general, contain appreciable quantities of digestible proteins, essential amino acids, bioactive peptides, long-chain polyunsaturated fatty acids, other carotenoids; vitamin $B_{12}$ and other vitamins; minerals, including copper, zinc, inorganic phosphate, sodium, potassium, selenium, iodine, and also other nutrients [7].

Therefore, the aim of this study was to utilize the chicken wings in processed chicken nuggets and use shellfish as a source of protein, vitamins and mineral, to produce healthy and economic products. The proximate compositions, nutritional value, physical and sensorial properties of these products were evaluated after preparation.

\section{Material and Methods}

\subsection{Material}

Fresh chicken wings, bread crumbs, wheat flour, fresh onions, fresh whole eggs, 
refined fine iodized common salt, black pepper, full cream cow milk and corn oil, were purchased from Alexandria local market, Egypt. Shell fish [undulate venus (Paphia undulata)], was obtained from Alexandria fish market.

\subsection{Methods}

\subsubsection{Technological Methods}

Preparation of the chicken wings: The chicken wings washed and steamed at $100^{\circ} \mathrm{C}$ for 15 minutes. to easily remove skin and separation chicken meat and cool at $4^{\circ} \mathrm{C}$.

Preparation of shellfish: Undulate venus (Paphia undulata) was soaked in tap water for $8 \mathrm{~h}$ with changing water every one hour, washed to remove mud, drained, steamed at $100^{\circ} \mathrm{C}$ for 10 minutes, cooled at room temperature to separation edible part, dehydrated at $55^{\circ} \mathrm{C}$ for $17 \mathrm{~h}$ and ground 2 times using Luska chopper.

Preparation of the chicken nuggets: Deboned skinless chicken wings meat were ground and well mixed with $5 \%$ bread crumbs, $4 \%$ of minced fresh onion, $0.1 \%$ salt and $0.1 \%$ black pepper. Four different formulations of the chicken nuggets were prepared as follows: control containing zero\% ground dehydrated shell fish, (CN $0 \%)$ three samples containing $2 \%, 4 \%$ and $6 \%$ of ground dehydrated shell fish (CN 2\%, CN 4\% and CN 6\%). The mixture of chicken nuggets was spread in a thin layer $(10 \mathrm{~mm}$ thickness), frozen $(2 \mathrm{~h})$ and shaped into discs of $3 \mathrm{~cm}$ diameter. The chicken nuggets were breaded using the following three step procedure: first they were coating with thin layer of wheat flour, and then immersing in mixture of 3:20 w/v whole liquid eggs to sterilizing liquid milk, following by coating with thin layer of fine ground bread crumbs. The breaded chicken nuggets kept at $4^{\circ} \mathrm{C}$ for at least 45 minutes before frying. The breaded chicken nuggets were frying at $180^{\circ} \mathrm{C}$ for approximately $4-5$ minutes, until an internal temperature of $80^{\circ} \mathrm{C}$ was reached.

Cooking loss of chicken nuggets: The breaded chicken nuggets were frying in pan at $140^{\circ} \mathrm{C}$ until center temperature reached $80^{\circ} \mathrm{C}$, then cooled to room temperature $\left(22^{\circ} \mathrm{C} \pm 3^{\circ} \mathrm{C}\right)$. The cooking loss was calculated using the following equations as mentioned by [8].

$$
\text { Cooking loss }(\%)=\frac{w_{1}-w_{2}}{w_{1}} \times 100
$$

where:

$w_{1}$ : weight of chicken nuggets sample before cooking; $w_{2}$ : weight of chicken nuggets sample after cooking.

Pick-up of coating: The pick-up coating was calculated according to [9].

$$
\text { Pick-up coating }=\frac{\text { weight with coating }- \text { weight without coating }}{\text { weight with coating }} \times 100
$$

\subsubsection{Analytical Method}

1) Physicochemical properties: The colour values, lightness $\left(\mathrm{L}^{*}\right)$, redness $\left(\mathrm{a}^{*}\right)$ 
and yellowness $\left(b^{*}\right)$, of food samples were evaluated using a Hunter Lab Ultra Scan, VIS model, colorimeter (USA). The instrument was standardized during each sample measurement with a black and white tail $\left(\mathrm{L}^{*}=94.1, \mathrm{a}^{*}=1.12, \mathrm{~b}^{*}=\right.$ 1.26). Mean of five readings of each colour index of Hunter scale $\left(L^{*}, a^{*}, b^{*}\right)$ were recorded [10].

Texture Profile Analysis (TPA) of chicken nuggets was performed using TA-XT 2 Texture meter (Texture Pro CT3 V1.2, Brookfield, Middleboro, USA) as described by [11]. Force time deformation curves were obtained during applying a $5 \mathrm{~kg}$ load cell, at a $1 \mathrm{~mm} / \mathrm{s}$ cross head speed. The following texture attributes were calculated hardness, cohesiveness, springiness, gumminess and chewiness, hardness = maximum force required to compress the sample, springiness $(\mathrm{mm})=$ ability of sample to recover its original form after a deforming force was removed cohesiveness = extent to which sample could be deformed prior to rupture the total energy required for first compression and the total energy required for the second compression); gumminess = force necessary to disintegrate a semisolid sample for swallowing, chewiness = work to masticate the sample for swallowing

Water Holding Capacity (WHC) of chicken nuggets was determined using filter paper press method [12].

\section{2) Chemical analysis:}

Proximate composition: Moisture, crude protein, crude fat and ash contents of chicken nuggets were determined according to the [13] while carbohydrates were calculated by difference.

Thiobarbituric Acid (TBA) was calorimetrically estimated according to [14] using UV-VIS Spectrophotometer Laxo alpha 1102, suit and expressed as mg malonaldehyde per kilogram fat or sample.

$\mathrm{pH}$ was determined using $\mathrm{pH}$ meter type MVX100 Beckman (USA) at room temperature $\left(22^{\circ} \mathrm{C} \pm 3^{\circ} \mathrm{C}\right)$ as described in [13].

Heavy metals: $\mathrm{Pb}, \mathrm{Cd}$ and $\mathrm{Cu}$ concentration in chicken nuggets sample were determined after digestion using ICP-OES according to the method of [15].

Minerals determination: $\mathrm{Ca}, \mathrm{Fe}, \mathrm{Na}, \mathrm{K}, \mathrm{Zn}, \mathrm{Mg}$ and $\mathrm{Mn}$ were determined using Inductively Coupled Plasma Atomic Emission Spectroscopy (ICP-OES) according to standard method US EPA Meth d 200.7 and US EPA Method 6010 C.

Vitamins: Vitamin A, E, and D were determined by HPLC System Controller (SCL-6A) using a Shimadzu CTO 6-A column supplies with a SPD-6AV detector (Japan), under high-pressure solvent delivery unit (LC-20AD) according to [16]. $20 \mu \mathrm{l} \mathrm{sample}$ volume was run at a flow rate of $2 \mathrm{ml} / \mathrm{min}$ for 15 minutes at $20^{\circ} \mathrm{C}$. Vitamin A, E and vitamin D were identified and quantified by comparing their retention times to known previously injected standards.

\subsubsection{Sensory Evaluation}

Colour, texture, taste, odour and overall acceptability of cooked chicken nuggets were organoleptically evaluated using 10 trained panelists from, Food Science 
and Technology Department, Faculty of Agriculture, Alexandria University. They were asked to rate their acceptabilities of cooked chicken nuggets products according to nine point scale, ranging from the like extreme 9 to dislike extreme 1 point as described by [17].

\subsubsection{Statistical Analysis}

Data was statistically analyzed using Statistical Package for Social Sciences (SPSS) software version 22 . The level of significant difference was determined at $P \leq$ 0.05 . Mean \pm Standard Deviation (SD) of mean was used.

\section{Results and Discussion}

\subsection{Chemical Composition}

\subsubsection{Heavy Metals Concentration}

Table 1 showed the concentration of $\mathrm{Pb}, \mathrm{Cd}$, and $\mathrm{Cu}$ in shellfish (Paphia undulata) before use in chicken nuggets preparation, there was no detection of $\mathrm{Pb}$ and $\mathrm{Cd}$ but, $\mathrm{Cu}$ concentration was $2.77 \mathrm{mg} / \mathrm{kg}$. These indicated that all heavy metals were less than the maximum permissible level proposed by [18] [19] and [20]. So this product was safe to use in processing chicken nuggets.

\subsubsection{Proximate Composition}

Results in Table 2 showed significantly reduction in moisture content indifferent chicken nuggets treatments. moisture was observed ranged from 57.92 in $\mathrm{CN} 0 \%$ to $62.64 \%$, in CN6\%, these differences in moisture due to addition dehydrated shellfish to the raw material, contain small quantity of dehydrate shellfish by $2 \%, 4 \%$ and $6 \%$, reflected lower moisture content of dehydrated shellfish. [21] showed that nuggets with reduced fat content $(25 \%)$ and the addition of wheat flour (10\% to $20 \%$ ), found moisture contents varying between $57.40 \%$ and $61.12 \%$, higher moisture values being found for the treatments with the addition of wheat flour.

On dry weight basis, the four prepared chicken nuggets with dehydrated shellfish were rich in protein values were $27.97 \%, 37.87 \%, 40.56 \%$ and $41.49 \%$, respectively for the different prepared chicken nuggets supplemented with dehydrated shellfish, $\mathrm{CN} 0 \%, \mathrm{CN} 2 \%, \mathrm{CN} 4 \%$ and $\mathrm{CN} 6 \%$. There was significantly increasing in

Table 1. Heavy metals concentration $(\mathrm{mg} / \mathrm{kg}$ ) in edible portions of shellfish (Paphia undulata) before use as ingredient in chicken nuggets.

\begin{tabular}{cccc}
\hline Heavy metals & $\begin{array}{c}\text { Concentration }(\mathrm{mg} / \mathrm{kg}) \\
\text { Wwb* }^{*}\end{array}$ & $\begin{array}{c}\text { Maximum Permissible } \\
\text { level }(\mathrm{mg} / \mathrm{kg})\end{array}$ & Recommended by \\
\hline Lead $(\mathrm{Pb})$ & N.D $^{* * *}$ & 2.0 & FAO $(1992)$ \\
& & 0.1 & $\operatorname{EOSQC~}(1993)^{* *}$ \\
Cadmium $(\mathrm{Cd})$ & N.D & 3.0 & FAD $(2001)$ \\
Copper $(\mathrm{Cu})$ & 2.77 & 0.1 & $($ EOSQC, 1993) \\
\hline
\end{tabular}

${ }^{*}$ Wet weight basis. ${ }^{*}$ Egyptian Organization for Standardization and Quality Control (EOSQC, 1993). ${ }^{* * *}$ not detected. 
Table 2. Effect of addition dehydrated shellfish on proximate composition, $\mathrm{pH}$ and TBA mg malonaldehyde/Kg of chicken nuggets.

\begin{tabular}{lrrrr}
\hline \multicolumn{1}{c}{ Component (\%) } & CN 0\% & CN 2\% & CN 4\% & \multicolumn{1}{c}{ CN 6\% } \\
\hline $\begin{array}{l}\text { 1-Moisture } \\
\text { 2-Proximate composition (\%) on }\end{array}$ & $62.64^{\mathrm{a}} \pm 0.06$ & $61.55^{\mathrm{b}} \pm 0.45$ & $60.65^{\mathrm{c}} \pm 0.31$ & $57.92^{\mathrm{d}} \pm 0.34$ \\
dry weight basis & & & & \\
Crude protein & $27.97^{\mathrm{c}} \pm 0.50$ & $37.87^{\mathrm{b}} \pm 0.57$ & $40.56^{\mathrm{a}} \pm 0.55$ & $41.49^{\mathrm{a}} \pm 0.60$ \\
Crud fat & $16.63^{\mathrm{a}} \pm 0.52$ & $14.76^{\mathrm{b}} \pm 0.55$ & $14.84^{\mathrm{b}} \pm 0.39$ & $14.91^{\mathrm{b}} \pm 0.29$ \\
Ash & $1.33^{\mathrm{d}} \pm 0.12$ & $1.78^{\mathrm{c}} \pm 0.08$ & $2.07^{\mathrm{b}} \pm 0.10$ & $2.81^{\mathrm{a}} \pm 0.11$ \\
Carbohydrate & $54.07^{\mathrm{a}} \pm 0.91$ & $45.59^{\mathrm{a}} \pm 0.91$ & $42.53^{\mathrm{c}} \pm 0.71$ & $40.79^{\mathrm{c}} \pm 0.32$ \\
Total caloric value (kcal/100g) & 477.83 & 466.68 & 465.92 & 469.31 \\
Percentage of protein calories to & 23.41 & 32.38 & 34.82 & 35.36 \\
total cal & & & & \\
pH value $_{\text {TBA }}^{* *}$ & $6.12^{\mathrm{c}} \pm 0.01$ & $6.17^{\mathrm{a}} \pm 0.01$ & $6.14^{\mathrm{b}} \pm 0.01$ & $6.14^{\mathrm{b}} \pm 0.01$ \\
\hline
\end{tabular}

Control Chicken Nuggets $0 \%$ dehydrated shellfish (CN $0 \%$ ), Chicken Nuggets with $2 \%$ shellfish (CN $2 \%$ ), Chicken Nuggets with $4 \%$ dehydrated shellfish (CN 4\%), Chicken Nuggets with $6 \%$ dehydrated shellfish $(\mathrm{CN} 6 \%){ }^{*}$ Calculated by difference. ${ }^{* *} \mathrm{mg}$ malonaldehyde/Kg sample. Data as mean $\pm \mathrm{SD}$. Means in the same column sharing the same letters are not significantly different at $P \leq 0.05$ level.

protein content $(P<0.05)$ in all chicken nuggets in comparison to the control. This means that addition of dehydrated shellfish increased protein content in nuggets and protein content increasing with increasing contain ratio of dehydrated shellfish that due to its high protein contain. Protein content in chicken nuggets comes mainly from raw meat so a higher amount of raw meat used in the formulation will result in higher protein content.

[22] reported that the removal of fat from chicken skin using sodium bicarbonate increased the protein content in bologna sausage.

[23] indicated that Paphia undulata contains higher protein contents, especially sarcoplasmic protein and myofibril protein, and it's a good source of protein, consisting of approximately $68.77 \%$ crud protein (dry weight basis). According to [24] chicken proteins have a high biological value due to their quantity and quality, containing types and ratio of amino acids very similar to those required for maintenance and growth of human tissue.

Fat content ranged from $14.76 \%$ to $16.63 \%$. It was significantly higher in CN $0 \%$ than $\mathrm{CN} 2 \%, \mathrm{CN} 4 \%$ and $\mathrm{CN} 6 \%$. This difference was attributed to addition of dehydrated shellfish, the major source of fat in such chicken nuggets was milk fat and egg during breading process. [25] showed that the lipid contents of several shellfish have very low lipid contents.

Also four chicken nuggets prepared with dehydrated shellfish content ash ranged from (1.33\% to $2.81 \%)$, carbohydrates from (40.79 to 54.07$)$ and total calories of the different chicken nuggets varied from 465.92 to $477.83 \mathrm{Kcal} / 100 \mathrm{~g}$ food. The percent protein derived calories were ranged from $23.41 \%$ to $35.36 \%$ among the different chicken nuggets prepared with dehydrated shellfish are low in calories due to their low lipid and carbohydrate contents [7].

The proximate composition of commercial chicken nuggets ranged of moisture $(34.71 \%-56.51 \%)$, protein $(12.52 \%-16.62 \%)$, fat $(18.14 \%-25.00 \%)$, Ash 
$(1.20 \%-1.58 \%)$ and carbohydrate content $(7.52 \%-26.49 \%)[26]$.

\subsection{3. $\mathrm{pH}$ and TBA}

The results in Table 2 showed that $\mathrm{pH}$ values, ranged from 6.12 to 6.17 in different in chicken nuggets prepared with dehydrated shellfish. Significant gradual rise in $\mathrm{pH}$ value, of all chicken nuggets was noticed. These values were within the normal limits for such products and they were in the agreement with the data found by [27] in fish nuggets. The $\mathrm{pH}$ of an uncooked chicken nugget ranged from 6.30 to 6.38 [28].

The TBA values of chicken nuggets prepared with dehydrated shellfish were showed no significant difference among the treatments $(P>0.05)$ ranged from 0.45 to $0.51 \mathrm{mg}$ malonaldhyde/Kg sample, CN $0 \%$ presented the lowest TBA value and it was no significant difference $(P<0.05)$ showing that the addition of dehydrated shellfish.

\subsubsection{Mineral Content}

Data in Table 3 showed that using dehydrated shellfish in preparing chicken nuggets caused a marked rise in its content of $\mathrm{Ca}, \mathrm{Fe}, \mathrm{Na}, \mathrm{K}, \mathrm{Zn}, \mathrm{Mg}$, and $\mathrm{Mn}$, levels, CN 0\% had the lowest concentration of all minerals $(55.91,1.58,202.24$, 201.60, 1.5, 21.08 and $0.22 \mathrm{mg} / 100 \mathrm{~g}$ ) respectively but $\mathrm{CN} 6 \%$ had the highest concentration $(89.51,6.61,263.02,303.15,4.23,39.30$ and $0.46 \mathrm{mg} / 100 \mathrm{~g})$ respectively. It is clear from the data that an addition dehydrated shellfish caused increasing in $\mathrm{Fe}, \mathrm{Zn}$ and $\mathrm{Mn}$, with $\sim 167 \%, 182 \%$ and $109 \%$ respectively from control. Shellfish minerals contain both macroelements (sodium, potassium, calcium phosphate and magnesium, iron, selenium zinc and manganese. [29] [30] and [31], most shellfish are good sources of $\mathrm{Na}, \mathrm{K}, \mathrm{Pi}, \mathrm{Fe}, \mathrm{Zn}, \mathrm{Se}$, and $\mathrm{Cu}$. Indian shrimp has $\mathrm{Na}, \mathrm{K}, \mathrm{Ca}, \mathrm{Mg}$, and $\mathrm{Pi}$ at 107, 58, 303, 250, and $176 \mathrm{mg} / 100 \mathrm{~g}$ raw edible meat, respectively [32].

Moreover, essential minerals such as $\mathrm{Zn}$ and Se have been reported as having beneficial effects such as antioxidant compounds and regulators of the immune system and the body function [33].

The daily consumption of $100 \mathrm{~g}$ of chicken nuggets would represent $6.4 \%$ [34].

Table 3. Effect of addition dehydrated shellfish on minerals contents $\mathrm{mg} / 100 \mathrm{~g}$ of chicken nuggets.

\begin{tabular}{ccccc}
\hline Minerals mg/100g & CN 0\% & CN 2\% & CN 4\% & CN 6\% \\
\hline $\mathrm{Ca}$ & 55.91 & 66.30 & 87.38 & 89.51 \\
$\mathrm{Fe}$ & 1.58 & 2.47 & 5.10 & 6.61 \\
$\mathrm{Na}$ & 202.24 & 224.48 & 261.24 & 263.02 \\
$\mathrm{~K}$ & 201.60 & 212.29 & 265.43 & 303.15 \\
$\mathrm{Zn}$ & 1.50 & 1.50 & 2.31 & 4.23 \\
$\mathrm{Mg}$ & 21.08 & 32.11 & 33.15 & 39.30 \\
$\mathrm{Mn}$ & 0.22 & 0.35 & 0.42 & 0.46 \\
\hline
\end{tabular}

Control Chicken Nuggets $0 \%$ dehydrated shellfish (CN 0\%), Chicken Nuggets with 2\% shellfish (CN 2\%), Chicken Nuggets with $4 \%$ dehydrated shellfish (CN 4\%), Chicken Nuggets with $6 \%$ dehydrated shellfish (CN 6\%). 
- 9.6\% of the recommended daily allowance for $\mathrm{Zn}$ for a healthy adult (8 - 12 $\mathrm{mg} /$ day). It can therefore be stated that consumption of this kind of product contributes to the recommended level of this essential minerals, as would a diet containing other products rich in $\mathrm{Zn}$. From this result $\mathrm{CN}$ 6\% had considerable value of $\mathrm{Zn}$.

\subsubsection{Vitamin A, E, and D}

Results in Table 4 showed that chicken nuggets containing dehydrated shellfish were rich in vitamins $\mathrm{A}, \mathrm{E}$ and $\mathrm{D}$ than chicken nuggets without dehydrated shellfish, all vitamins were increasing with increasing ratio of dehydrated shellfish was added, CN 0\% had lower value of vitamins $\mathrm{A}$, as (1432.35 IU/100g), E as $(161.09 \mathrm{mg} / 100)$ and $\mathrm{D}$ as $(201.94 \mu \mathrm{g} / 100 \mathrm{~g})$, but $\mathrm{CN} 6 \%$ had higher value of all vitamins $\mathrm{A}$ as $(8530.95 \mathrm{IU} / 100 \mathrm{~g}), \mathrm{E}$ as $(724.70 \mathrm{mg} / 100)$ and $\mathrm{D}$ as $(885.88 \mu \mathrm{g} / 100 \mathrm{~g})$. Shellfish species contain most of the vitamins; shrimp, blue mussel, oyster, and scallop are good sources of vitamin A Shrimp recorded vitamin D3 content of about $0.06 \mu \mathrm{g} / 100 \mathrm{~g}$ [35]. Therefore addition dehydrated shellfish to chicken nuggets was main reason in increasing vitamins value and producing healthy product.

\subsection{Physicochemical and Sensorial Properties}

Colour: Results in Table 5 showed that yellowness represented the main fraction of the actual colour of the chicken nuggets due to colour of tissue of poultry

Table 4. Effect of addition dehydrated shellfish on vitamins contents chicken nuggets.

\begin{tabular}{ccccc}
\hline Vitamins & CN0\% & CN2\% & CN4\% & CN6\% \\
\hline Vitamin (A) IU/100g & 1432.35 & 6741.28 & 8474.21 & 8530.95 \\
Vitamin (E) $\mathrm{mg} / 100 \mathrm{~g}$ & 161.09 & 184.59 & 246.47 & 724.70 \\
Vitamin (D) $\mu \mathrm{g} / 100 \mathrm{~g}$ & 201.94 & 390.20 & 595.11 & 885.88
\end{tabular}

Control Chicken Nuggets 0\% dehydrated shellfish (CN 0\%), Chicken Nuggets with 2\% shellfish (CN 2\%), Chicken Nuggets with $4 \%$ dehydrated shellfish (CN 4\%), Chicken Nuggets with $6 \%$ dehydrated shellfish (CN $6 \%)$.

Table 5. Effect of addition of dehydrated shellfish on colour and texture of chicken nuggets.

\begin{tabular}{ccccc}
\hline Parameter & CN 0\% & CN 2\% & CN 4\% & CN 6\% \\
\hline 1-Colour & & & & \\
Lightness $\left(\mathrm{L}^{*}\right)$ & 68.28 & 66.17 & 65.85 & 63.96 \\
Redness $\left(\mathrm{a}^{*}\right)$ & 3.11 & 3.10 & 2.83 & 2.49 \\
Yellowness (b*) & 18.29 & 20.79 & 20.80 & 21.29 \\
2-Texture & & & & \\
Hardness (g) & 425 & 554 & 556 & 682 \\
Cohesiveness & 0.81 & 0.98 & 1.03 & 1.02 \\
Springiness (mm) & 6.68 & 6.04 & 5.67 & 5.56 \\
Gumminess (g) & 543 & 545 & 568 & 599 \\
Chewiness (mJ) & 33.6 & 35.6 & 39.2 & 43.6 \\
\hline
\end{tabular}

Control Chicken Nuggets $0 \%$ dehydrated shellfish (CN $0 \%$ ), Chicken Nuggets with $2 \%$ shellfish (CN $2 \%$ ), Chicken Nuggets with $4 \%$ dehydrated shellfish (CN 4\%), Chicken Nuggets with $6 \%$ dehydrated shellfish (CN 6\%). 
meat and dehydrated shellfish was added therefore yellowness increasing with increasing the addition ratio of dehydrated shellfish, and reduction on lightness and redness was noticed at the same time in chicken nuggets. When compared the Control Nuggets ( $\mathrm{CN} 0 \%)$ to the other treatments found that it had the lowest value of yellowness 18.29 and had highest value of lightness $\left(\mathrm{L}^{*}\right) 66.28$ but $\mathrm{CN}$ $6 \%$ had highest value 21.29 . of yellowness and, had lowest value 63.96 of lightness. Redness had slightly reduction with dehydrated shellfish was added to chicken nuggets (3.11 to 2.49 ). In poultry products, $\mathrm{L}^{*}$ is the most important value as it measures lightness and is the easiest for consumers to detect [36]. Redness is determined by a positive value in the $\mathrm{a}^{*}$ measurement of the colour chicken nuggets with high $\mathrm{a}^{*}$ values indicate a reddish appearance of the meat block [2]. Cooked nuggets were lighter and less red than the raw nuggets, similar to what occurred during breast poultry meat cooking [37].

Texture: Data in Table 5 showed slightly changes in hardness, cohesiveness, springiness, gumminess and chewiness were noticed. Generally when dehydrated shellfish was increased, hardness, gumminess and chewiness parameters were increased, however the lowest hardness value was 425 in control (CN 0\%) this means that hardness was less in chicken nuggets containing high moisture, $\mathrm{CN}$ 6\% had highest value of hardness as (682). cohesiveness, springiness, gumminess and chewiness ranged from (0.81 to 1.03), (5.56 to 6.68), (543 to 599) and (33.6 to 43.6) respectively, and $\mathrm{CN} 0 \%$ the lowest value in all texture parameter except springiness but $\mathrm{CN}$ 6\% was the highest one in all parameter except springiness. Due to the protein content of the various ingredients, it was expected that there would be different effects on textural properties of chicken nuggets [2]. However the changes in all parameter but chicken nuggets were still much tenderer.

Physicochemical properties: The data in Table 6 showed significant $(P<$ $0.05)$ increase in WHC, pick-up, and cooking loss of chicken nuggets prepared with added dehydrated shellfish were ranged from (48.36 to 59.98), (29.28 to 34.21 ) and (4.05 to 4.63) respectively. WHC had lowest value in CN0\% with highest content of fat. Water holding capacity values proportional with early content of products, where water holding capacity values were low in products high in fat. The water holding capacity functionality nature was influenced by how far effective protein matrix binding scattered excess fat and water in products

Table 6. Effect of addition of dehydrated shellfish on physicochemical properties WHC, pick-up and cooking loss of chicken nuggets.

\begin{tabular}{ccccc}
\hline Physicochemical properties & CN 0\% & CN 2\% & CN 4\% & CN 6\% \\
\hline WHC (\%) & $48.36^{\mathrm{d}} \pm 0.72$ & $55.35^{\mathrm{c}} \pm 0.53$ & $57.61^{\mathrm{b}} \pm 0.62$ & $59.98^{\mathrm{a}} \pm 0.19$ \\
Pick-up & $29.28^{\mathrm{d}} \pm 0.05$ & $30.00^{\mathrm{c}} \pm 0.11$ & $30.60^{\mathrm{b}} \pm 0.11$ & $34.21^{\mathrm{a}} \pm 0.17$ \\
Cooking loss & $4.05^{\mathrm{c}} \pm 0.13$ & $4.16^{\mathrm{bc}} \pm 0.14$ & $4.38^{\mathrm{b}} \pm 0.09$ & $4.63^{\mathrm{a}} \pm 0.11$ \\
\hline
\end{tabular}

${ }^{*}$ Data as mean $\pm \mathrm{SD}$. Means in the same column sharing the same letters are not significantly different at $P$ $\leq 0.05$ level. Control Chicken Nuggets $0 \%$ dehydrated shellfish (CN 0\%), Chicken Nuggets with $2 \%$ shellfish (CN 2\%), Chicken Nuggets with 4\% dehydrated shellfish (CN 4\%), Chicken Nuggets with 6\% dehydrated shellfish (CN 6\%). 
Table 7. Effect of addition of dehydrated shellfish on sensory properties of chicken nuggets.

\begin{tabular}{ccccc}
\hline Sensory properties & CN 0\% & CN 2\% & CN 4\% & CN 6\% \\
\hline Odour & $8.70^{\mathrm{a}} \pm 0.67$ & $8.60^{\mathrm{a}} \pm 0.96$ & $9.00^{\mathrm{a}} \pm 0.05$ & $8.40^{\mathrm{a}} \pm 0.69$ \\
Colour & $8.80^{\mathrm{a}} \pm 0.42$ & $8.40^{\mathrm{ab}} \pm 0.26$ & $8.90^{\mathrm{a}} \pm 0.32$ & $7.80^{\mathrm{b}} \pm 0.78$ \\
Taste & $8.90^{\mathrm{a}} \pm 0.32$ & $8.20^{\mathrm{bc}} \pm 0.91$ & $8.80^{\mathrm{ab}} \pm 0.42$ & $7.60^{\mathrm{c}} \pm 0.96$ \\
Texture & $8.80^{\mathrm{a}} \pm 0.63$ & $8.70^{\mathrm{a}} \pm 0.48$ & $8.70^{\mathrm{a}} \pm 0.48$ & $7.70^{\mathrm{b}} \pm 0.95$ \\
Appearance & $8.80^{\mathrm{a}} \pm 0.42$ & $8.70^{\mathrm{a}} \pm 0.67$ & $8.80^{\mathrm{a}} \pm 0.42$ & $8.00^{\mathrm{b}} \pm 0.52$ \\
Overall acceptability & $8.90^{\mathrm{a}} \pm 0.32$ & $8.50^{\mathrm{a}} \pm 0.71$ & $8.40^{\mathrm{a}} \pm 0.52$ & $7.80^{\mathrm{b}} \pm 0.79$ \\
\hline
\end{tabular}

${ }^{\star}$ Data as mean $\pm \mathrm{SD}$. Means in the same column sharing the same letters are not significantly different at $P$ $\leq 0.05$ level.

[38]. Control (CN 0\%) had lowest value of pick-up and cooking loss when $\mathrm{CN}$ $6 \%$ the highest one. Cooking loss is equivalent with emulsion stability. It is an important parameter for assessing the quality of meat products. Breakdown of emulsion occurs with increasing temperature and will increase cooking losses [39]. [40] found higher levels of cooking loss for chicken nuggets formulated with banana flour and soybean skin ( $1 \%$ to $5 \%)$ as compared to the control treatment.

[27] reported that the mean pick-up values differed $(P<0.05)$ among the different fish nuggets, which were between $20.07 \%$ and $27.98 \%$.

Sensory properties: According to sensory evaluation panelists accepted the chicken nuggets (Table 7). The degree of the preference of colour, odour, taste, texture and overall acceptability was very good. Also, they showed that addition of dehydrated shellfish not impact their acceptability and preference degrees of their sensory qualities. Data in Table 7 showed the chicken nuggets $\mathrm{CN} 4 \%$ had highest score compared with $\mathrm{CN} 0 \%, \mathrm{CN} 2 \%$ and $\mathrm{CN} 6 \%$. This mean addition of dehydrate shellfish improved sensory properties of chicken nuggets prepared from chicken-wings.

\section{Conclusion}

Results of this study confirmed the successful use of chicken wings in producing healthier chicken nuggets and addition dehydrated shellfish show increasing in protein, minerals and vitamins; and improving physicochemical and sensory properties.

\section{Conflicts of Interest}

The authors declare no conflicts of interest regarding the publication of this paper.

\section{References}

[1] BEDCA/AESAN (2019) Spanish Food Composition Database (BEDCA). http://www.bedca.net/bdpub/

[2] Yeater, M., Casco, G., Miller, R.K. and Alvarado, C.Z. (2017) Comparative Evaluation of Texture Wheat Ingredients and Soy Proteins in the Quality and Acceptabili- 
ty of Emulsified Chicken Nuggets. Poultry Science, 96, 4430-4438. https://doi.org/10.3382/ps/pex250

[3] Banerjee, D.K., Das, A.K., Banerjee, R., Pateiro, M., Nanda, P.K. and Gadekar, Y.P. (2020) Application of Enoki Mushroom (Flammulina velutipes) Stem Wastes as Functional Ingredients in Goat Meat Nuggets. Foods, 9, 432. https://doi.org/10.3390/foods9040432

[4] Fernández-Ginés, J.M., Fernández-López, J., Sayas-Barberá, E. and Pérez-Alvarez, J.A. (2005) Meat Products as Functional Foods: A Review. Journal of Food Science, 70, 37-43. https://doi.org/10.1111/j.1365-2621.2005.tb07110.x

[5] Scott, M.L. (1956) Composition of Turkey Meat. Journal of the American Dietetic Association, 32, 941-944.

[6] Mora, L., Reig, M. and Toldr, F. (2014) Bioactive Peptides Generated from Meat Industry by-Products. Food Research International, 65, 344-349. https://doi.org/10.1016/j.foodres.2014.09.014

[7] Nettleton, J.A. and Exler, J. (1992) Nutrients in Wild and Farmed Fish and Shellfish. Journal of Food Science, 57, 257-260. https://doi.org/10.1111/j.1365-2621.1992.tb05470.x

[8] El-Magoli, S.S., Laroia, S. and Hasen, P. (1996) Flavor and Texture Characteristics of Low Fat Ground Beef Patties Formulated with Whey Protein Beef Patties Formulated with Whey Protein Concentration. Meat Science, 42, 179-193.

https://doi.org/10.1016/0309-1740(95)00032-1

[9] Barros, J.C., Munekata, P.E.S., Pires, M.A., Rodrigues, I., Andaloussi, O.S., Rodrigues, C.E.C. and Trindade, M.A. (2018) Omega-3- and Fibre-Enriched Chicken Nuggets by Replacement of Chicken Skin with Chia (Salvia hispanica L.) Flour. LWT: Food Science and Technology, 90, 283-289.

https://doi.org/10.1016/j.lwt.2017.12.041

[10] Santipanichwing, R. and Suphantharika, M. (2007) Carotenoids as Colorants in Reduced-Fat Mayon-Naise Containing Spent Brewer's Yeast $\beta$-Glucan as a Fat Replacer. Food Hydrocolloids, 21, 565-574.

https://doi.org/10.1016/j.foodhyd.2006.07.003

[11] Yuan, S. and Chang, S.K.C. (2007) Texture Profile of Tofu as Affected by Instron Parameters, Sample Preparation and Correlation of Instron Hardness and Springiness with Sensory Scores. Journal of Food Science, 72, 136-145. https://doi.org/10.1111/j.1750-3841.2006.00263.x

[12] Aman, M.B. (1983) Effect of Cooking and Preservation Methods on the Water Holding Capacity (WHC) of Mullet Fish in Relation with Changes Occurred in Muscle Proteins. Zeitschrift fur Lebensmittel-Untersuchung und-Forschung, 177, 345-347. https://doi.org/10.1007/BF01042194

[13] AOAC (2000) Official Methods of Analysis. 17th Edition, Association of Official Analytical Chemists, Gaithersburgh, Maryland.

[14] Park, S.Y., Yoo, S.S., Hu, J., Euv, J.B., Lee, H.C., Kin, Y.J. and Chin, K.B. (2007) Evaluation of Lipid Oxidation and Oxidative Products as Affected by Pork Meat Cut Packaging Method and Storage Time during Frozen Storage $\left(-10^{\circ} \mathrm{C}\right)$ Journal of Food Science, 72, 114-119. https://doi.org/10.1111/j.1750-3841.2006.00265.x

[15] Vitosevic, B., Samardzic, S., Antonijevic, V. and Jokovljevic, V. (2007) Heavy Metals in Some Imported Food Products and Their Potential Toxic Implications. Medicus, 8, 62-66.

[16] AOAC (Association of Official Analytical Chemists) (2012) Official Methods of Analysis. 19th Edition, Chapter 4, Association of Official Analytical Chemists, Gaithersburgh, USA, 9-13. 
[17] Meilgaard, M., Civille, G.V. and Carr, B.T. (1999) Sensory Evaluation Techniques. 3rd Edition, CRC, Boca Raton, 8-12. https://doi.org/10.1201/9781003040729

[18] FAO (Food and Agriculture Organization) (1992) Committee for Inland Fisheries of Africa: Report of the Third Session of the Working Party on Pollution and Fisheries. FAO Fisheries \& Aquaculture, No. 471, p. 43.

[19] FDA (Food and Drug Administration) (2001) Fish and Fisheries Products Hazards and Controls Guidance. 3rd Edition, Centre for Food Safety and Applied Nutrition, US Food and Drug Administration.

[20] Egyptian Organization for Standardization and Quality Control (EOSQC) (1993) Maximum Residue Limits for Heavy Metals in Food "Ministry of Industry". Cairo, Egypt.

[21] Santhi, D. and Kalaikanannan, A. (2014) The Effect of the Addition of Oat Flour in Low-Fat Chicken Nuggets. Journal of Nutrition \& Food Sciences, 4, 206.

[22] Bonifer, L.J., Froning, G.W., Mandigo, R.W., Cuppett, S.L. and Meagher, M.M. (1996) Textural, Color, and Sensory Properties of Bologna Containing Various Levels of Washed Chicken Skin. Poultry Science, 75, 1047-1055. https://doi.org/10.3382/ps.0751047

[23] He, X.Q., Cao, W.H., Zhao, Z.K. and Zhang, C.H. (2013) Analysis of Protein Composition and Antioxidant Activity of Hydrolysates from Paphia undulate. Journal of Food and Nutrition Research, 1, 30-36.

[24] Selgas, C.E., Garciá, M.L. and Selgas, M.D. (2006) Design of a New Cooked Meat Sausage Enriched with Calcium. Meat Science, 73, 368-377.

https://doi.org/10.1016/j.meatsci.2005.12.016

[25] Hossain, Z. and Takahashi, K. (2012) Health Benefits of Bio-Functional Marine Lipids. Proceedings of the 2nd International Congress on Seafood Technology on Sustainable Innovative and Healthy Seafood, Anchorage, May 2010, 209-214.

[26] Lukman, I., Nurul, H. and Noryati, I. (2009) Physicochemical and Sensory Properties of Commercial Chicken Nuggets. Asian Journal of Food and Agro-Industry, 2, 171-180.

[27] Silva, M.C.A., Leite, J.S.A.F., Barreto, B.G., Neves, M.V.A., Silva, A.S., Viveiros, K.M. and Cavalheiro, C.P. (2021) The Impact of Innovative Gluten-Free Coatings on the Physicochemical, Microbiological, and Sensory Characteristics of Fish Nuggets. LWT-Food Science and Technology, 137, Article ID: 110409. https://doi.org/10.1016/j.lwt.2020.110409

[28] Kim, H.-Y., Kim, K.-J., Lee, J.-W., Kim, G.-W., Choe, J.-H., Kim, H.-W., Yoon, Y. and Kim, C.-J. (2015) Quality Evaluation of Chicken Nugget Formulated with Various Contents of Chicken Skin and Wheat Fiber Mixture. Journal for Food Science of Animal Resources, 35, 19-26. https://doi.org/10.5851/kosfa.2015.35.1.19

[29] Dong, F.M. (2001) The Nutritional Value of Shellfish. Washington Sea Grant: WSG-MR 09-03. U.S. National Oceanic and Atmospheric Administration, Seattle, 4-8.

[30] Souci, S.W., Fachman, W. and Krant H. (2008) Food Composition and Nutritiontables. 7th Edition, Medpharm Scientific Publishers, Stuttgart, 1300.

[31] USDA (U.S. Dept. of Agriculture) (2012) Food Composition Databases. USDA National Nutrient Database for Standard Reference.

[32] Gopakumar, K. (1997) Biochemical Composition of Indian Food Fishes. Central Institute of fisheries technology, India. http://www.cift.res.in

[33] Oropeza-Moe, M., Wisløff, H. and Bernhoft, A. (2015) Selenium Deficiency Associated Porcine and Human Cardiomyopathies. Journal of Trace Elements in Medicine Biology, 31, 148-156. https://doi.org/10.1016/j.jtemb.2014.09.011 
[34] Lorena, M., Gaspar R. and Gema N. (2020) Effect of Natural Extracts Obtained from Food Industry By-Products on Nutritional Quality and Shelf Life of Chicken Nuggets Enriched with Organic Zn and Se Provided in Broiler Diet 2020. Poultry Science, 99, 1491-1501. https://doi.org/10.1016/j.psj.2019.11.008

[35] Bogard, J.R., Thilsted, S.H., Marks, G.C., Wahab, M.A., Hossain, M.A.R., Jakobsen, J. and Stangoulis, J. (2015) Nutrient Composition of Important Fish Species in Bangladesh and Potential Contribution to Recommended Nutrient Intakes. Journal of food composition and analysis, 42, 120-33.

https://doi.org/10.1016/j.jfca.2015.03.002

[36] Guidi, A. and Castigliego, L. (2010) Poultry Meat Color. In: Guerrero-Legarreta, I., Ed., Handbook of Poultry Science and Technology. John Wiley \& Sons, Inc., Hoboken, 359-388. https://doi.org/10.1002/9780470504475.ch25

[37] Fletcher, D.L., Qiao, M. and Smith, D.P. (2000) The Relationship of Raw Broiler Breast Meat Color and $\mathrm{pH}$ to Cooked Meat Color and pH. Poultry Science, 79, 784-788. https://doi.org/10.1093/ps/79.5.784

[38] Foegeding, E.A. and Lanier, T.C. (1989) The Contribution of Non-Muscle Protein Foods. In: Phillips, R.D. and Finley, J.W., Eds., Protein Quality and the Effects of Processing, Marcel Dekker, New York, 331.

[39] Townsend, W.E., Ackerman, S.A., Witnauer, L.P., Palm, W.E. and Swift, C.E. (1971) Effects of Types and Levels of Fat and Rates and Temperatures of Comminution on the Processing and Characteristics of Frankfurters. Journal of Food Science, 36, 261-265. https://doi.org/10.1111/j.1365-2621.1971.tb04038.x

[40] Kumar, V., Biswas, A.K., Sahoo, J., Chatli, M.K. and Sivakumar, S. (2013) Quality and Storability of Chicken Nuggets Formulated with Green Banana and Soybean Hulls Flours. Journal of Food Science and Technology, 50, 1058-1068.

https://doi.org/10.1007/s13197-011-0442-9 